\title{
Cambodia's Higher Education Development in Historical Perspectives (1863-2012)
}

\author{
Sam Rany \\ (Corresponding author) \\ School of Educational Studies, Universiti Sains Malaysia, PO box 11800, Penang, Malaysia \\ Tel: (+60) 17-506-3234 Email: sr11_edu045@student.usm.my

\begin{abstract}
Ahmad Nurulazam Md Zain
School of Educational Studies, Universiti Sains Malaysia, PO box 11800, Penang, Malaysia

Tel: 604- 65-329-71 Email: anmz@usm.my
\end{abstract}

Hazri Jamil

School of Educational Studies, Universiti Sains Malaysia

PO box 11800, Penang, Malaysia, Tel: 604-653-2989Ｅmail: hazri@usm.my

Received: March 17, 2012

Doi: 10.5296/ijld.v2i2.1670
Accepted: April 20, $2012 \quad$ Published: April 21, 2012

URL: http://dx.doi.org/10.5296/ijld.v2i2.1670

\begin{abstract}
Similar to other Southeast Asian countries in the world, Cambodia has established her higher education institutions to develop human capital with high knowledge and professional ethics to serve the country over the period of contemporary history. Clearly, colonization, political ideologies, and global economic development tendencies have directly influenced Cambodian public higher education institutions within her various political regimes and social transformation. The purpose of this study is to examine the Cambodian higher education development in the seven different regimes through historical perspectives from the French colonial period to the present period. This paper uses a predominantly descriptive approach relying on secondary sources such as academic papers, textbooks, government documents, non government organization documents, and development partner reports. Therefore, this research could be significant for researchers, academicians, and policymakers to deepen their understanding about Cambodian higher educational history in order to reform its system to the benefit of education quality and student academic success.
\end{abstract}


Keywords: Cambodia, higher education institutions, development, historical perspectives, public university, education system, tertiary education

\section{Introduction}

Historically, Cambodia established its first higher educational institution during the Angkor Empire, which was a powerful kingdom in the Southeast Asian region in the $12^{\text {th }}$ century. During this glorious period, it had two main universities located in Preah Khan temple (Vat Cheysrey) and Taprom temple (Raja Vihear) under the administration of Andradevy, the queen of King Jayavarman VII (1181-1220). In this medieval time, temples had a significant role in promoting educational, cultural, and innovative activities. Consequently, about 1081 ancient famous temples were constructed nationwide as a result of this fruitful period. Moreover, there were 18 individuals with doctoral degrees (cultural and religious intellectuals) and 740 university teachers to transform the Khmer elite to enhance the national human resource capital of the country (PUB, 2009).

After the decline of Angkor in the $15^{\text {th }}$ century, Cambodian higher learning institutions were destroyed and closed because of wars and invasions from the neighboring countries included Thailand and Vietnam. In these hardship periods, pagodas became the best educational and professional institutions for Khmer scholars and intellectuals. To stop the aggressive ambition of these two countries, Cambodian King Ang Duong (1797-1860) invited France to be Cambodia's protectorate in 1863. Under the French protectorate and colonization, France tried to transform the Cambodian traditional education system into a modern or western educational system. In addition, many public schools and higher learning institutions were established throughout the country. During the post colonization period, Prince Sihanouk paid more attention to tertiary education through the building up of many higher education institutions nationwide. For example, Unfortunately, Cambodian fell into the cold war in 1970, and tertiary education also experienced growing pains during a turbulent 23 year period (1970-1993) resulting in a decimated educational system. Tragically, during the Democratic Kampuchea regime (DK) between 1975 and 1979, most Cambodian intellectuals, scholars, and academics were lost in the genocide. After the civil war was over in 1998, however, Cambodia has strived to develop and reform her higher education institutions until now.

Therefore, this paper will investigate the historical perspectives of Cambodian higher education development during the French protectorate and colonization, the Prince Sihanouk period, the Khmer Republic period, the Democratic Kampuchea period, the Vietnamese occupation period, the UNTAC and Coalition government period, and the Hun Sen period.

\section{Cambodian higher education development from a historical perspective}

The higher educational system in Cambodia has been divided into seven stages in its development because each phase presents the ideological and political regime at that point of 


\section{Ml Macrothink}

the history of Cambodia. The country experienced many ideologies and politic which comprised traditionalism, colonialism, Buddhist socialism, monarchy, republicanism, Maoist communism, Vietnamese communism, United Nations transactional authority, and a hybrid democracy respectively. Each regime amended the national constitution and educational policies to its own liking. For example, Prince Sihanouk founded the Royal Khmer University (RKU) during his rule on January 13, 1960. This university had changed its name to the Phnom Penh University (PPU) during the Khmer Republic or Lon Nol's regime in 1970. In 1980, it has been converted to the Higher Normal College (Ecole Normale Superieure) during the Vietnamese occupation. Ultimately, this name has been changed to the Royal University of Phnom Penh (RUPP) in 1996. This section will highlight a historical perspective in each stage of the development.

\subsection{Under the French protectorate and colonization (1863-1953)}

This section discusses Cambodian education historical perspectives prior to and under French colonization. Prior to the French colonial period, pagodas were the educational and professional training centre of the nation. The Cambodian education system was characterized as community-based pagoda institutions, where Buddhist monks had independent and important educational duties to transfer their knowledge with the integration of religious and cultural instructions. For instance, monks would instruct boys and youth in carpentry skills mixed with Khmer literacy closely associated with the concepts of Buddhism and Cambodian culture. During the pre-colonial period, as only pagodas were seen as educational centers for the Cambodian people, the majority of the people were illiterate. There were no other schools. Consequently, Ayres has argued that most Cambodian people learned their rich cultural heritage through the country's popular proverbs and sayings, traditional law (didactic poems), epics such as the Reamker (Khmer version of the Ramayana Indian story), and folk tales via word of mouth (Ayres, 2000). Therefore, the main purpose of education during this period was to educate young men with the general knowledge about life and society such as social ethics, life skills, as well as to attain a certain degree of basic literacy (Dy, 2004).

Similarly, during the 90 years of French protectorate and colonization (August 11, 1863 to November 9, 1953), France introduced its own administrative and educational system in Cambodia, which seemed to be somewhat successful in its efforts. After four years of the protectorate, King Norodom (1834-1904), grandfather of Prince Sihanouk, established the first school for 40 students of the royal family using French as the language of instruction. Shortly thereafter, France opened the first public schools in Phnom Penh, Kampot, Kampong Cham, and Kraties in 1873, and founded the first training centre for colonial administrators and officers in 1893 (Masson, 1997). In 1906, King Sisowath issued a royal edict on compulsory education requiring parents to send their sons and daughters to study basic Khmer literacy and mathematics at the age of eight. The first Cambodian Civil Code was promulgated in 1915 in which articles 356 and 357 stated parents' obligation to provide their children with education. In 1917, the Cambodian School of Administration (Ecole d'Administration Cambodgience) was founded to train young people to be civil servants in the country. In 1935, Sisowath High 
School (Lycee Sisowath), the country's oldest and sole secondary school, was opened for Cambodian students with a low standard of education when compared with western secondary schools.

As cited in (Duggan, 1996), Galasso (1990) analyzed the gaps between traditional and modern education. He maintained that most rural children attended pagoda schools, which combined traditional and modern teaching methodologies whereas a small group of provincial towns and Phnom Penh capital allowed students to access Franco-Khmer schools under a French system with a four year primary program. And another four years of lower secondary school was leading to the Franco-Khmer Secondary School Diploma; and then a three year secondary program leading to the Baccalaureate that would allow enrolment in French universities. During that time, there were a few post secondary schools and higher learning institutions in the country so that only wealthy and state-sponsored outstanding students had opportunities to further their higher learning overseas. Consequently, a small elite group was able to study at French universities in France or Vietnam. As highlighted by Tully, national education during the colonial period faced crucial problems. The vast majority of schools suffered from poor teaching methodology, lack of resources and financial support, unqualified teachers and the misunderstanding of peasants who withheld their children from attending public schools provided by the French colonial power. Also, a clash occurred between the traditional values of the monk-teachers and the content of a new curriculum based on European modern thinking (Tully, 2002). Surprisingly, the first Cambodian higher learning institution, namely the National Institute of Juridical, Political and Economic Sciences (NIJPES), was established for Cambodian scholars who intended to be civil servants in the colonial government in 1949 (Ayres, 2000; Howard, 1967; Tully, 2002). A study by Clayton \& Ngoy (1997) pointed out that the French government used higher education as a "sorting machine to recruit the best students from basic education for advanced education in order to equip the country with a large number of modern and competent civil servants" (Clayton, 1997). In short, it can be concluded that the educational system during the colonial period experienced some problems with the integration of traditional and western educational systems, with funding constraints, unqualified teachers, and inferior educational quality.

\subsection{Under the Prince Sihanouk (1953 -1970)}

Cambodia was granted peaceful independence from France at the Geneva Conference on November 9, 1953. Prince Sihanouk strove to promote educational policies from basic education to tertiary education, to transform the country into an industrialized and technologically advanced modern state in the region. The king subsequently created two very efficient political mechanisms: the People's Socialist Community (Sangkum Reastr Niyum-SRN), and the movement of Socialist Youth of the Khmer Kingdom (SYKK). The government of King Sihanouk allocated more than $20 \%$ of its annual national expenditure for a massive educational expansion program to consolidate his ideology of "Buddhist socialism" to educate Cambodian students and youth to adopt loyalty to the monarchy and Marxist egalitarianism," (Ayres, 2000, p. 449). Moreover, he reformed the French- related curriculum, 


\section{MIMacrothink}

which was a legacy of colonialism, into a Cambodian curriculum covering Khmer culture, history, arts, and science etc. (Clayton, 2005). As a result of this policy, the number of primary, secondary schools, and new universities increased dramatically throughout the country (Chendler, 2008). Remarkably, seven higher educational institutions were established between 1953 and 1959 including the National Institute for Law, Politics, and Economics (1953), the Royal Medical School (1953), the Royal School for Public Administration (1956), the National Institute of Pedagogy (1958), the Faculty of Letters and Humanity Studies (1959), the Faculty of Science and Technology (1959), and the National School of Commerce (1959) (Chhum, 1973). Furthermore, nine public and prestigious universities appeared in provincial and municipal territories. The Buddhist University, a first university in this regime, was opened in 1954 offering religious studies and Khmer language studies, and the Royal Khmer University followed in 1960. Five years later, six additional universities emerged in 1965 comprising of the Royal Technical University (RTC), the Royal University of Fine Arts (RUFA), the Royal University of Kompong Cham (RUKC), the Royal University of Takeo-Kampot (RUTK), the Royal University of Agricultural Science (RUAS), and the People's University (PU) (Pit, 2004), and lastly, the Royal University of Battambang (RUBB) which opened in 1967. French was used as the language of instruction in most universities and higher learning institutions. Enrolment in higher educational institutions dramatically increased from approximately 200 students in 1953 to 5753 students in 1970 . This signified a great achievement in the history of Cambodian higher education (Howard, 1967). To sum up, it was a significant period of rapid development of Cambodian modern educational system during the People's Socialist Community.

Table 1: The list of Universities and Institute under the Prince Sihanouk

\begin{tabular}{|c|l|c|}
\hline No. & \multicolumn{1}{|c|}{ Universities/Faculties/Institutes/Schools } & Date of Establishment \\
\hline 1 & The National Institute for Law, Politics, and Economics & 1953 \\
\hline 2 & The Royal Medical School (RMS) & 1953 \\
\hline 3 & The Buddhist University (BU) & 1954 \\
\hline 4 & The Royal School for Public Administration (RSPA) & 1956 \\
\hline 5 & The National Institute of Pedagogy (NIP) & 1958 \\
\hline 6 & The National School of Commerce (NSC) & 1959 \\
\hline 7 & $\begin{array}{l}\text { The Faculty of Letter and Humanities (FLH) } \\
\end{array}$ & The Faculty of Science and Technology (FLH) \\
\hline 8 & The Royal Khmer University (RKU) & 1960 \\
\hline 9 & The Royal Technical University (RTC) & 1965 \\
\hline 10 & The Royal University of Fine Arts (RUFA) & 1965 \\
\hline 11 & The Royal University of Kompong Cham (RUKC), & 1965 \\
\hline 12 & The Royal University of Takeo-Kampot (RUTK) & 1965 \\
\hline 13 & The Royal University of Agricultural Science (RUAS) & 1965 \\
\hline 14 & The People University (PU) & 1967 \\
\hline 15 & The Royal University of Battambang (RUBB) & \\
\hline
\end{tabular}




\subsection{Under the Khmer Republic (1970-1975)}

After the coup d'état on March 18, 1970, the Lon Nol government ousted Prince Sihanouk as head of state. He abolished the monarchy, and announced a new constitution that changed Cambodia into the Khmer Republic under the support of the United States government. Similar to Prince Sihanouk's policy, the Lon Nol government had considered education expansion as a priority for the success of the country's development (Ayres, 2000). Unfortunately, higher education in this period was confronted with social and political issues resulting from the cold war, in particular, the influence of the ideology of a new regime dominated by western concepts of republicanism, capitalism, and democracy. The controversy of these political ideologies as well as a nationwide civil war destabilized the education program between 1970 and 1975 (Ayres, 2000; Chendler, 2008). In addition, the Khmer Republican government actively fought against the Viet Cong and the Khmer Rouge. About 600,000 Cambodian citizens were killed by aerial bombardments between 1969 and 1973 (Ear, 1995). Because of war and insecurity, most schools and universities were either destroyed or forced to close with almost 200 foreign lecturers fleeing the universities and the country (Chhum, 1973). Consequently, there were few local lecturers, who had qualified experiences to provide educational services in Cambodian universities. The University of Takeo-Kampot was completely destroyed by aerial bombardments on 1 May 1970, the University of Kompong Cham was partially destroyed, and the University of Battambang was totally closed in early 1971. According to Tan Kim Houn (1974), there were only five urban and two provincial universities that remained open to provide educational services and these were the University of Phnom Penh (UPP), the University of Fine Arts (UFA), the University of Agronomic Science (UAS), the Buddhist University (BU), and the Technical University (TU). In the academic year of 1971-72, the enrollment rates of universities either remarkably increased or decreased because students fled to the countryside or to safe places. For instance, the enrollment of the UPP significantly increased from 4547 in 1970 to 6840 in 1971, while the TU decreased from 573 in 1970 to 298 in 1971, the UFA increased slightly from 117 to 155 and two provincial universities decreased from 357 in 1970 to 37 in 1972. In summary, the educational system during the Khmer Republic faced problems of ideological disputes, the cold war, shortage of qualified local lecturers, and reduction in the number of educational facilities, substandard teaching and research work, resulting in inferior educational quality.

Table 2: The list of universities under the Khmer Republic (1970-1975)

\begin{tabular}{|c|l|c|}
\hline No. & \multicolumn{1}{|c|}{ Universities/College/Institutes } & Date of Establishment \\
\hline 1 & The University of Phnom Penh (UPP) & 1970 \\
\hline 2 & The University of Fine Arts (UFA) & 1970 \\
\hline 3 & The Technical University (TU). & 1970 \\
\hline 4 & The University of Agronomic Science (UAS) & 1970 \\
\hline 5 & The Buddhist University (BU) & 1970 \\
\hline 6 & The University of Takeo-Kampot (UTK) & 1970 \\
\hline 7 & The University of Kompong Cham (UKC) & 1970 \\
\hline 8 & The University of Battambang (UB) & 1970 \\
\hline
\end{tabular}




\subsection{Under the Khmer Rouge (1975 -1979)}

After Khmer Rouge took over the country on 17 April 1975, Pol Pot immediately established the Democratic Kampuchea government (DK) led by the Communist Party of Kampuchea (CPK). The DK, imitating the Cultural Revolution of the People Republic of China, implemented the national policy of "self-reliance" and "self-mastery" to turn the country into an agrarian society to develop its economy. Even though the government provided schools throughout the country, they only furnished basic education for the purpose of their political ideology in order to achieve the policy of an agrarian revolution (Ayres, 2000: 106, 118). Over the next three years, eight months and 20 days, the Khmer Rouge systematically eliminated all existing social, economic, political and cultural infrastructure in the country (Chendler, 2008). Cambodian higher education institutions also fared badly. Under the Democratic Kampuchea regime, about 1.7 million Cambodians were decimated through executions, overworking, starvation, and disease. Educational facilities were completely destroyed, and approximately 75 percent of higher educational lecturers and 96 percent of university students were lost in genocide (Pit, 2004). Of the 21,000 trained secondary school teachers in 1975, about 3000 had survived in 1979 (David, 1999). For example, prior to the DK, Cambodia had 5,275 primary schools, 146 secondary schools, and 9 higher education institutions, but about 90 percent of these educational facilities and all their documents were completely destroyed under this regime. In addition, this regime wanted to destroy the legacy of previous regimes by releasing the country from the clutches of capitalism, western ideas, thinking and institutions, poverty and corruption in major cities throughout the country (David Ayres, 1999).

According to Vickery (1984) as cited in (Tomas Clayton, 1998), Pol Pot created new a educational policy, namely, the 1976 Four Year Plan (1976-1980) to build socialism in all areas that required all children to attend at least three years of a part-time primary school program. Pol Pol had an extreme vision to fast track the education of Cambodian students from illiteracy to become an engineering graduate in 10 years of training and practical works. The most popular slogan during this regime was "Study is not important. What's important is work and revolution." As highlighted by Chandler (1993), the DK ignored educational quality by recruiting uneducated peasants, based on their revolutionary positions and honesty, to be teachers and to teach students during lunch breaks in a 14 hour workday. Moreover, DK introduced many revolutionary songs depicting national sacrifices in the curriculum of reading, writing, arithmetic, geography, natural science, physics, chemistry, history of the Cambodians, world revolutionary struggle, the party's politics, and moral philosophy in order to transform students and to purify their political consciousness (Ayres, 1999). In short, the failures of DK's extreme communist ideology and its educational policy brought Cambodia to year zero of the destruction of education in the country. 
2.5. Under the Vietnamese occupation (1979 - 1991)

After the collapse of Democratic Kampuchea on January 7, 1979, a new government with the support of Vietnamese forces was established, namely the People's Republic of Kampuchea (PRK) or the United Front for the National Salvation of Kampuchea (UFNSK) guided by the Kampuchea People's Revolutionary Party (KPRP), and led by Heng Samrin. During the Vietnamese invasion and occupation, the war extended contentiously throughout the country. Many Cambodians had little trust in the Vietnamese-backed new government because Vietnam had always been Cambodia's enemy in its longstanding history. The regime also faced controversial disputes with the international community, which imposed economic and political sanctions on both the new People's Republic of Kampuchea (PRK) and Vietnam (Ayres, 2000). ASEAN states (Thailand, Singapore, Malaysia, Philippine, and Indonesia), China, and the United States sponsored Cambodian armed forces resistance along the Cambodia-Thailand border.

During this period of hardship, PRK started to restore the educational system by calling survivors to be teachers and trainers in schools and institutions of higher learning. According to Hun Sen, the government implemented its policy of "people with low education teach the ones with no education", "people with high education teach the ones with low education"(Sen, 2011 ). During this period, five main Cambodian higher and technical educational institutions adopted hybrid systems from the Soviet Union, Vietnam, and other Eastern-bloc countries. These countries provided technical assistance with both human resources and teaching materials at all levels including higher education (Ayres, 2003). Higher educational institutions had major roles to provide good political and technical training to promote the ideology of socialism. In order to achieve this goal, tertiary students were required to study five main areas including Marxist-Leninist Theories, Global and Cambodian Revolutionary Histories, Situation and the Role of the Revolution and the Policy of the Party, Moral Education and the Revolutionary Way of Life, and Attitude to the Common People (Clayton, 1999). In December 1979, the Faculty of Medicine and Dentistry, the first higher learning institution, was opened by the new government. Approximately 10-20 medical doctors from the Vietnamese Ministry of Health came to train the few surviving Cambodian students who had not completed their medical studies before the DK regime. This faculty offered a six year medical program. In July 1980, the Teacher Training College was established, and about 40 Vietnamese professors from the Vietnamese Ministry of General Education trained Cambodian students who had not graduated from their higher educational institutions before 1975. This college offered a three year program to become high school teachers. In September 1981, the Khmer Soviet Friendship Higher Technical Institute was established with the full support from the Soviet Union financially, technically, and in the area of human resources. About 56 Soviet professors provided lectures in six different majors including Civil Engineering, Electronics and Electrical Engineering, Industrial Chemistry, Agro-Hydrology, Mines and Mining, and Geology from 1980 to 1989. The Institute of Economics was established in September 1984 with the full support of Vietnam by providing all professors, text books, as well as the curricula. Approximately 35-40 Vietnamese professors, who came from the University of 
Economics in Hanoi, taught the five major areas of Agro-Economics, Industrial Economics, Commerce, Finance, and Economic Planning. In January 1985, the Institute of Agriculture opened under the financial and technical support of the Ukraine Agricultural Academy. About 56 professors from other institutions in the Soviet Union came to teach in the five major areas of Agronomy, Forestry, Fisheries, Veterinary Medicines, and Agricultural Mechanics. In addition, many students were sent to study at friendly countries through educational and cooperation agreements.

According to Virak (2009), 6,509 students were sent abroad to study between 1979 and 1989, among them, 1,426 were females. Cambodian students who received scholarships from receiving countries to study abroad included 159 students to Bulgaria, 60 to Cuba, 300 to the Czech Republic, 1179 to East Germany, 191 to Hungary, 25 to Laos, 30 to Mongolia, 80 to Poland, 3730 to Russia, and 751 to Vietnam (Virak, 2009). In 1989, the People's Republic of Kampuchea (PRK) changed its name to the State of Cambodia (SC) after the withdrawal of the Vietnamese army and the collapse of Soviet Union (RU). By 1990, 977 students graduated from Cambodian higher educational institutions to become doctors, dentists, and pharmacists, 2,196 to become high school teachers, 1,481 students as foreign language specialists, 474 students as technical engineers, 400 students as economists, and 184 students as agricultural engineers respectively. In brief, the higher education institutions during the Vietnamese occupation were dominated by political ideology of socialism and inferior education equality and they depended absolutely on the financial and technical support of countries with friendship agreements, but they were the first professionally trained technical experts in Cambodia. Many women assumed leadership roles that they had never been able to assume before. Girls had equal rights to access higher education, as did boys for the first time in Khmer history.

Table 3: The list of Universities and Institute under the Vietnamese occupation

\begin{tabular}{|c|l|l|}
\hline No. & \multicolumn{1}{|c|}{ Universities/College/Institutes } & \multicolumn{1}{|c|}{ Date of Establishment } \\
\hline 1 & The Faculty of Medicine and Dentistry (FMD) & December 1979 \\
\hline 2 & The Teacher Training College (TTC) & July 1980 \\
\hline 3 & The Khmer Soviet Friendship Higher Technical Institute & September 1981 \\
\hline 4 & The Institute of Economics (IE) & September 1984 \\
\hline 5 & The Institute of Agriculture (IA) & January 1985 \\
\hline
\end{tabular}

\subsection{Under the UNTAC and the Coalition Government (1991 - 1997)}

This period was a new beginning of reform, restructuring and development of Cambodian higher educational institutions. After a decade of civil war and two years of negotiations, the Cambodian conflicting parties, which were the Cambodian's People Party (CPP), the Democratic Kampuchea (DK), the National United Front for Neutral, Peaceful and Cooperative Cambodia (FUNCEPEC), and the Khmer People's National Liberation Front (KPNLF), signed the Paris Peace Accord on October 23, 1991 initiated by the United Nations 
in order to end the longstanding war in Cambodia (UNESCO, 2011). The UN Security Council established the United Nations Transitional Authority in Cambodia (UNTAC) to ensure the implementation of the peace agreement, and the organization of free and fair elections.

During the transition period from 1991-1993, there were very few educational changes conducted by UNTAC because the government retained control over the administration of the existing education sector. After the general election in 1993, the new constitution and a coalition government were established to facilitate the organization and implementation of national policies. The new government proclaimed its commitment to develop human resources and capacity building by increasing to at least 15 percent of public expenditure of the whole national budget on education although it fell from 11.8 percent in 1996-97 to 8.3 percent in 1998-99 (Ayres, 2000). In 1994, the government together with the sponsoring international development partners created a national development strategy entitled "National Program to Rehabilitate and Develop Cambodia (NPRD)" in which human resource development was one of its key pillars. A project of the United National Development Program (UNDP), "the Capacity Building for Education and Human Resources Sector Management", a support to the government, was eventually converted into the "Program to Rebuild Quality Education and Training in Cambodia" through the government's ratification at the National Education Seminar in January 1994. Two review projects of the Asian Development Bank, Basic Education Investment Plan (1995-2000) and Education Investment Plan were adopted by the government in December 1994 and were incorporated into the Cambodia's First Socio-economic Development Plan, 1996-2000. Furthermore, the government changed two major policies to expand higher educational institutions in 1997.

First, the government permitted public HEIs to provide classes based on private tuition fees for non-scholarship students in a limited number of institutions. In addition, top government-supported scholarship students were recruited by the Ministry of Education, Youth, and Sports. Second, the government allowed private sectors to be involved in Higher Educational investment (Pit, 2004). Virak highlighted (2009) that between 1989 and 1999, 2,170 Cambodian students were awarded scholarships to study abroad, among them, 187 were female students. Records showed that 112 students went to Australia, 24 to Canada, 22 to the Czech Republic, 32 to France, 148 to Germany, 4 to Hungary, 20 to Indonesia, 142 to Japan, 10 to Laos, 12 to Poland, 769 to Russia, 34 to Thailand, 30 to USA, and 797 to Vietnam (Virak, 2009). Unfortunately, this coalition government broke up following a bloody coup on July 5-6, 1997. In brief, the development of Cambodian higher education in this period was faced many problems in providing educational services because of political instability and civil war.

\subsection{Under the Hun Sen regime (1998-the present)}

After the civil war was over, a new government was announced by Prime Minister Hun Sen in 1998. Hun Sen has ruled the country as Cambodian prime minister for three mandates of 
government in 1998-2003, 2003-2008, and 2008-2013 respectively. Meanwhile, Cambodian higher education has been analyzed by different educational experts as "a cause for concern," "plagued with difficulty," and "in a ferment of concern." It reflects a number of problems with higher learning institutions: they are centrally supervised by the government ministries; they operate with limited financial resources and are fraught with political interference without transparency of academic recruitment, university leader appointment, and program approval (Ford, 2006). Presently, there are 91 Cambodian higher education institutions, which comprise 34 public and 57 private universities, in 19 provinces and in Phnom Penh, the capital. Not suprisingly, the expansion of higher education institutions is reflected in the growth in the number of enrollments. According to a report of the Ministry of Education, the total annual registration rate has increased dramatically to more than four times from 41,000 to 173,000 between 2003 and 2010, with approximately 91 percent of fee-paying students in the public and private HEIs. In particular, in the academic year 2010-2011, there were 981 doctorate students, 12,887 master students, 173,264 undergraduate students, and 20,719 associate students (MoEYS, 2011b). Due to the growth in number of HEIs and enrolments, scholars describe the Cambodian higher education landscape as undergoing a "silent revolution" (Rockefeller Foundation Supported Project, 2006). Many private universities have mushroomed to provide educational services throughout the country. Several factors have been observed during the rapid growth of private higher education institutions in this short period of time.

First, low salaries in the public sector have led to the loss of more and more government university lecturers to private institutions that offer well-paid salaries. Second, conflicting educational and political ideologies between young and old Cambodian scholars have caused young scholars to switch to the private sector. Third, private higher education institutions have striven to develop competitive marketing strategies in producing human capital for the labor market after Cambodia became a member of ASEAN in 1999 and the WTO in 2004 (Leng, 2010). Hence, there are five main critical areas to be urgently reformed in order to effectively improve the educational quality for Cambodian students and to ensure academic success for Cambodian HEIs (Chealy, 2009).

\subsubsection{Constraints of higher education financing}

Financing higher education is virtually limited by the government's annual budget. Overall, educational expenditure amounts to $1.60 \%$ of the GDP while public higher education expenditure receives only $0.05 \%$ of the GDP (WB, 2012). For example, government has been financing public higher education institutions in the amount of 3, 0243.8 million Riels (approximately US\$ 8 million) in 2011, and it will be dramatically increased to 5, 4620.0 million Riels (approximately US\$ 13 million) in 2012. A large portion of the budget of Higher Education is spent on staff remuneration with a smaller portion on development of other subsectors. Due to financial constraints and lack of support, the government allows public HEIs to run private classes to generate tuition fees to support their institutional operation. There are two components of the government budget to HEIs: the Recurrent 
Budget (RB), which covers salaries, utilities, water, and non salary expenditure, and the Program Budget (PB), which covers three subcomponents, i.e. Teachers, students and institutional development.

Beside the government budget, many international partners and donors have a major role in supporting Cambodian HEIs. The Asian Development Bank (ADB) and the World Bank (WB) are especially significant contributors who help Cambodian Higher Education. For instance, ADB currently has a US\$ 25 million project to assist in improving the quality of education. In this project, US\$ 3 million is targeted to support HEIs in three subcomponents, namely improving the HR department, strengthening the accreditation mechanism, and improving the library of the Royal University of Phnom Penh (ADB, 2010). Furthermore, the World Bank has approved a five year project from 2011 to 2014 to the amount of US\$ 23 million to support HEIs in the following four main areas strengthening the capacity of higher education system (1), providing competitive development and innovation grants (2), offering scholarships to disadvantaged students and project management (3), and monitoring and evaluating its project (4) (WB, 2011). Briefly, financing problems are certainly important factors that affect the education quality in Cambodian tertiary education.

Table 4: Financing plan for higher education in Cambodia (MoEYS, 2011)

Cost in Riel Millions

\begin{tabular}{|l|l|l|l|l|l|}
\hline Activities & 2009 & 2010 & 2011 & 2012 & 2013 \\
\hline $\begin{array}{l}\text { Institutional support and } \\
\text { operation }\end{array}$ & $6,238.7$ & 6,7524 & $2,9185.4$ & $5,2708.3$ & $7,8294.0$ \\
\hline $\begin{array}{l}\text { Monitoring and evaluation } \\
\text { and quality strengthening }\end{array}$ & 256.3 & 233.6 & $1,058.4$ & $1,911.7$ & $2,842.0$ \\
\hline Resources: Total & $6,495.0$ & $6,7757.6$ & $3,0243.8$ & $5,4620.0$ & $8,1136.5$ \\
\hline
\end{tabular}

Source: Report on Goals of the Ministry of Education, Youth, and Sports in Academic Year 2009-2011.

\subsubsection{Admission requirements}

Most Cambodian public and private universities do not specify or stipulate admission requirements into their institutions. They rely solely on the results of the final national high school examinations. This means that students who have completed six years of primary and six years of secondary education with passing grades and secondary school diplomas do not need to apply for admission in order to enter tertiary educational institutions. Prior to 2002, similar to Soviet and European admission procedures to higher education, the government ministries prepared examinations to recruit the best candidates to enroll in the public higher educational institutions, but the private HEIs had already been setting their own entrance exams to recruit students under supervision by relevant ministries. Consequently, many public and private universities have selected unqualified students to attend their institutions. Thus, educational quality suffers a negative impact caused by the search for commercial benefits. 
Therefore, admission requirements cause controversial problems, while human resources, teaching quality, and research capacity are also crucial problems in the current Cambodian HEIs.

\subsubsection{Human resources, teaching quality, and research capacity problems}

The lack of human resources, teaching quality, and research capacity is also a major problem. There are few full time academicians who hold PhD's in Cambodian universities because of insufficient salaries and incentives. The monthly salary together with basic salary, functional, and subsidiary allowances (risk allowance, regional allowance, health risk allowance, pedagogic allowance, and family allowance) for a fulltime university lecturer can be as low as Riel 55, 0000 (approximately USD \$130), which is insufficient to meet the daily expenses of a family (RGC, 2010), whereas overall academic average monthly salaries of some Asian countries are much higher: they range from USD 1,182 in China, USD 1,547 in India, USD 2,568 in Australia, USD 3,107 in Malaysia, to USD 4,112 in Japan (Rumbley, 2008). Thus, public university lecturers prefer to take up part-time teaching at a number of academic institutions. Without adequate income from a normal teaching load, lecturers have to spend more time on teaching to make a living, leaving no time to do research. In this context, Cambodia needs qualified lecturers, educational experts, and policy makers to restore its system, but the lack of academic professionalization criteria is not encouraging people to work in academic institutions. According to the Cambodian Scientific Department (2010), there are 1510 masters' degree lecturers and 192 doctorates' degree lecturers in private and public HEIs nationwide. However, the Royal University of Law and Economics (RULE) and the Royal University of Phnom Penh (RUPP), both prestigious universities and member of ASEAN University Network, have only 7 and 16 PhD holders respectively (MoEYS, 2011a). Most universities around the world require their lecturers to fulfill three basic functions: to upgrade the quality of training, to do research, and to provide consultation services.

Conversely, Cambodian HEIs only require their lecturers to upgrade their quality of training. Presently, research work suffers much due to constraints of the government's financial support and lack of human resources. Some academic journals are being published by Cambodian higher education institutions. However, a recent study of five prestigious Cambodian HEIs has found that "only 6 percent of university lecturers hold PhD's degrees and approximately 85 percent have never published any academic or research papers (Chen, 2007). In conclusion, Cambodian higher education institutions need to increase their human capital with highly qualified, experienced and professionally skilled personnel to meet the minimum standards of education quality. Academic relevance is also one of the factors that can allow students to select suitable majors to match the needs of labor markets and society. 
Table 5: Staff statistics by highest qualification in top public universities

\begin{tabular}{|c|l|c|c|c|c|}
\hline No. & \multicolumn{1}{|c|}{ Name of Universities } & $\begin{array}{c}\text { Total } \\
\text { Fulltime } \\
\text { staff }\end{array}$ & $\begin{array}{c}\text { Bachelor } \\
\text { Holder }\end{array}$ & $\begin{array}{c}\text { Master } \\
\text { Holder }\end{array}$ & $\begin{array}{c}\text { PhD } \\
\text { Holder }\end{array}$ \\
\hline 1. & Royal University of Phnom Penh (RUPP) & 460 & 2 & 262 & 16 \\
\hline 2. & National University of Management (NUM) & 83 & 0 & 58 & 14 \\
\hline 3. & Royal University of Law and Economics (RULE) & 111 & 0 & 77 & 7 \\
\hline 4. & Chea Sim University of Komchaymea (CSUK) & 54 & 0 & 25 & 0 \\
\hline 5. & University of Svay Rieng (USV) & 73 & 0 & 55 & 0 \\
\hline 6. & University of Battambong (UBB) & 49 & 0 & 43 & 3 \\
\hline 7. & Mean Chey University (MCU) & 79 & 0 & 57 & 0 \\
\hline 8. & National Institute of Education (NIE) & 252 & 1 & 78 & 4 \\
\hline 9. & Institute of Technology of Cambodia (ITC) & 155 & 1 & 71 & 16 \\
\hline
\end{tabular}

Source: Education Staff Statistics by Current Status, Cadre, Qualification and Age Group National 2010-2011, the Ministry of Education, Youth, and Sports.

\subsubsection{Academic relevance}

Relevant skills in universities are not linked with the labour market. The high rate of unemployment among the university graduates is partly due to their lack of skills needed in the labour market. Public and Private HEIs are competing to providing the same subjects in business studies, economics and IT. Currently, employment in these areas is already fully saturated, while science, mathematics, agriculture and health are areas with national needs yet to be filled by skilled workers (Noch, 2009). In 2009, proximately 65,734 students (48 percent of total students) graduated with a Major in Commerce. Business studies are most popular among Cambodian students in both public and private universities because students and their parents think that these skills will allow them to find well paid salary positions in modernized and comfortable offices. According to a report of the Economic Institute of Cambodia (EIC), only 10 percent of the university graduates found jobs in 2007. However, the government fails to finance public universities to increase pure science majors enrollment because these majors require more spending of the national budget on workshops, laboratories and experiments. Moreover, the government still supports public universities to offer academic curricula that are generally provided by private universities. Therefore, it is evident that public sectors are competing commercially with private sectors within tertiary education without making any effort to meet social needs and economic growth of Cambodia as stipulated in the government's rectangular strategy (Chealy, 2009).

In short, Cambodian HEIs need to expand their curricula and facilities to provide a wide range of skills to link labor demands nationally and internationally. However, university autonomy and academic freedom are a part of the current problem to improve the education quality in Cambodia. 
2.8.5. Autonomy and academic freedom

The last problem is autonomy and academic freedom within the public universities. Presently, public HEIs, which are controlled by centralized ministry supervision, experience serious problems of underfunding and low salaries. According to (Chealy, 2009), Cambodian higher educational institutions are divided into two different categories namely, academic and vocational institutions. Academic institutions are supervised by the Ministry of Education, Youth, and Sport (MoEYS) while vocational institutions are under the supervision of the Ministry of Labour and Vocational Training (MoLVT). In addition, the Royal Academic of Cambodia (RAC), a research institution supervised by the Council of Ministers, offers Master's and $\mathrm{PhD}$ 's programs to Cambodian students. Hence, there are twelve specialized ministries and agencies that provide higher education services in Cambodia including the Ministry of Education, Youth, and Sports (MoEYS), the Ministry of Labour and Vocational Training (MoLVT), the Ministry of Health $(\mathrm{MoH})$, the Ministry of Economy and Finance (MoEF), the Ministry of Agriculture, Forestry, and Fisheries (MoAFF), the Ministry of Culture and Fine Arts (MoCFA), the Ministry of National Defence (MoND), the Ministry of Religious Affairs (MoRA), the Ministry of Interior (MoI), the Ministry of Public Work and Transportation (MoPWT), the National Bank of Cambodia (NBC) and the Office of the Council of Ministers (CoM) (UNESCO, 2006; Virak, 2010).

A few public universities are given legal status as quasi-government institutions or public administration institutions (PAIs). Political parties and parent ministries are actively involved in making important decisions in the administration of an HEI as well as nominating high academic ranking officers based on political tendency rather than academic qualifications in Cambodian public HEIs. For example, the presidents or rectors of public universities are appointed by the government without opening the positions to public competition and evaluation of academic experiences and competencies.

Cambodian HEIs are not mandated to grant diplomas; only parent ministries and agencies have absolute rights to issue, sign, and stamp on any diploma; high ranking government officers are cordially invited to preside in the graduation ceremony. In the current educational system, academic freedom is in its infancy because the freedom of expression related to politics, human rights, democracy, corruption, transparency, good governance, and social justice debates are banned within the HEIs. In addition, the government has imposed regulations on HEIs advertising their universities through mass media in order to maintain control over all advertisements before reaching the public because experiences of misconduct of some institutions in the past. Therefore, autonomy and academic freedom are still controversial problems in the current educational system caused by a legacy of communist ideology in the past. 


\section{Conclusion}

The purpose of this paper is to examine the historical context of Cambodian higher education development in seven different regimes from the French protectorate and colonization period to the Hun Sen period. This paper also provided a literature review of Cambodian traditional and modern education system within the framework of the political tendencies and ideologies of traditionalism, colonialism, Buddhist socialism, monarchy, republicanism, Maoist communism, Vietnamese communism, and a hybrid democracy. In conclusion, the discussion has suggested five main crucial problems of the current Cambodian higher education institutions to be urgently restored in order to effectively enhance the educational quality and to integrate her system into the ASEAN community in 2015.

\section{Acknowledgement}

The first author would like to thank Professor Dr. Roshada Hashim, Dean of the Institute of Postgraduate Studies and Associate Professor Dr. Rozinah Jamaludin, the Centre for Instructional Technology and Multimedia of the Universiti Sains Malaysia (USM) for their kind help and encouragement. This publication is supported by the USM PhD Fellowship to the first author.

\section{References}

Ayres, D. (1999). The Khmer Rouge and education: beyond the discourse of destruction. History of Education, 28(2), 205-208. http://dx.doi.org/10.1080/004676099284744

Ayres, D. (2000). Tradition, Modernity, and the Development of Education in Cambodia. Comparative Education Review, 4(4).

Ayres, D. (2003). Education and the localization of structural adjustment in Cambodia. In K. M. A. Welch (Ed.), Globalization and educational restructuring in the Asia Pacific region (pp. 232-261). New York: Palgrave Macmillan.

Chealy, C. (2009). Higher Education in Cambodia. In Y. Hirosato and Y. Kitamura (eds.) (Ed.), The Political Economy of Educational Reforms and Capacity Development in Southeast Asia (pp. 153-165): Springer Science, Business Media B.V. 2009.

Chendler, D. (2008). A history of Cambodia ( $4^{\text {th }}$ Edit). Boulder, Colo: Westview Press.

Chhum, S. (1973). Higher education in the Khmer Republic. In Y. Y. Hoong (Ed.), Development of higher education in Southeast Asia: Problems and issues (pp. 100-104). Singapore The regional institute of higher education and development

Chen, C., Sok, P., \& Sok, K. (2007). Benchmarking Potential Factors Leading to Educational Quality in Cambodia. Quality Assurance in Education, 15(2), 128-148. http://www.doi: $\underline{10.1108 / 09684880710748901}$ 
Clayton, T. (1998). Building the New Cambodia: Educational Destruction and Construction under the Khmer Rouge , 1975-1979. History of Education Quarterly 38(1 ), 1-16.

Clayton, T. (1999). Education under Occupation: Political Violence, Schooling, and Response in Cambodia, 1979-1989. Current Issues in Comparative Education, 2(1), 71-79.

Clayton, T. (2005). Re-orientations in moral education in Cambodia since 1975. Journal of Moral Education, 34(4), 505-517. http://www.doi: 10.1080/03057240500410236

Duggan, S. (1996). Education, Teacher Training and Prospects for Economic Recovery in Cambodia. Comparative Education, 32(3), 361-337. http://dx.doi.org/10.1080/030500 696 28768

Dy, S. (2004). Strategies and Policies for Basic Education in Cambodia: Historical Perspectives. International Education Journal, 5(1), 90-97.

Ear, S. (1995). Cambodia's Economic Development in Historical Perspective (1953-1970). The Belkeley McNAIR Journal, 3 (12).

Ford, D. (2006). Cambodia-Growing and Pains. International Higher Education (44), 2.

Howard, H. (1967). Higher Education and Development in the South East Asia (Vol. II ). Paris, France: United Nations Education, Scientific and Cultural Organization (UNESCO) and International Association of Universities (IAU).

Rumbley, L., Pacheco, I., \& Philip, A. (2008). International Comparison of Academic Salaries: A Exploratory Study USA: Boston College, Center for International Higher Education

Leng, P. (2010). Students' Perceptions toward Private Sector Higher Education in Cambodia. Unpublished Master of Art. University of Ohio, USA.

Masson, G., \& Fergusso, L. (1997). A culture under siege:post-colonial higher education and teacher education in Cambodia from 1953 to 1979. History of Education, 28(2), 13. http://dx.doi.org/10.1080/0046760970260106

MoEYS. (2011a). Education Staff Statistics by Current Status, Cadre, Qualification and Age Group National 2010-2011. Phnom Penh: The Ministry of Education, Youth, and Sports.

MoEYS. (2011b). Summary Report on the Education, Youth and Sport Performance in the Academic Year 2009-2010 and the Academic Year 2010-2011 GoalsPhnom Penh, Cambodia.

Noch, C. (2009). Higher Education and Unemployment of the Educated in Cambodia, . Master thesis, The International Institute for Educational Planning (IIEP), UNICEF, Paris. 


\section{Macrothink

Pit, C., \& Ford, D. (2004). Cambodian Higher Education: Mixed Visions In P. G. A. \& T. Umakoshi (Ed.), Asian Universities: Historical Perspectives and Contemporary Challenges (pp. 333-362 ). Baltimore and London: The Johns Hopkins University Press

PUB. (2009). History of Cambodia. Phnom Penh: Prahsihanoukraj Buddhist University (PUB)

RGC. (2010). Handbook for Civil Servants: Serving people better. Phnom Penh: The Council for Administrative Reform

Sen, H. (2011 ). Keynote Address at the Conferment of Certificate and Degree to Graduates of the University of Human Resources in August 11, 2011, Phnom Penh, Cambodia.

Clayton, T., \& Youk, N. (1997). Cambodia. In Gerard, P. \& Grace, M. (Ed.), Asian higher education (pp. 21-36). Westport, Conn.: Greenwood Press.

Tully, J. (2002). France on the Mekong: A history of the protectorate in Cambodia, 1863-1953. Lanham, Md.: University Press of America.

UNESCO. (2006). Higher Education in South-East Asia. Bangkok, Thailand: the UNESCO Asia and Pacific Regional Bureau for Education.

UNESCO. (2011). Education and Fragility in Cambodia. Paris, France: International Institute for Educational Planning.

Virak, Y. (2009). Student Mobility in Southeast Asia: The Case of Cambodia. Paper presented at the The Regional Seminar on Student Mobility in Southeast Asia. Kuala Lumpur, Malaysia.

Virak, Y. (2010). The Quality Assurance in Higher Education in South East Asian Countries: The Case of Cambodia Paper presented at the The Regional Seminar on Quality Assurance in Higher Education in Southeast Asia Countries, Bangkok, Thailand. [Online] Available: http://www.rihed.seameo.org/mambo/qa2009/cambodia_report.pdf

WB. (2011). Higher Education Quality and Capacity Improvement Project, Report No: ISR2317 (pp. 1-6). Phnom Penh: The World Bank.

WB. (2012). Putting Higher Education to Work : Skills and Research for Growth in East Asia (pp. 113-116). Washington, D.C.: The International Bank for Reconstruction and Development. 